\title{
Helminths Assemblage of the bare-faced ibis, Phimosus infuscatus (Lichtenstein, 1823) (Pelecaniformes: Threskiornithidae), in southern Brazil
}

\author{
Helmintos de Phimosus infuscatus (Lichtenstein, 1823) (Pelecaniformes: Threskiornithidae) no \\ extremo sul do Brasil
}

\begin{abstract}
Simone Scheer ${ }^{1 *}$ (D); Carolina Silveira Mascarenhas ${ }^{1}$; Márcia Raquel Pegoraro de Macedo ${ }^{1}$; Gertrud Muller ${ }^{1}$
${ }^{1}$ Laboratório de Parasitologia de Animais Silvestres - LAPASIL, Departamento de Microbiologia e Parasitologia, Instituto de Biologia, Universidade Federal de Pelotas - UFPel, Pelotas, RS, Brasil
\end{abstract}

Received July 01, 2018

Accepted January 03, 2019

\begin{abstract}
Birds act as hosts for a variety of parasites, many of these are unreported. The literature provides scant information on the helminth fauna of Phimosus infuscatus. The presence of helminths were investigate in 28 birds from Pelotas, Capão do Leão, and Rio Grande in Rio Grande do Sul. The preparation and identification of helminths followed protocols. Prevalence (P\%), mean intensity of infection (MII), and mean abundance (MA) were estimated. The following helminths were found: Hystrichis acanthocephalicus, Dioctophyme renale (larva), Porrocaecum heteropterum, Baruscapillaria sp., Aproctella carinii, Paradeletrocephalus minor, and Cyathostoma sp. (Nematoda); Echinostomatidae gen. sp., Tanaisia valida, and Athesmia sp. (Trematoda: Digenea) and Megalacanthus sp. (Cestoda). The most prevalent species were H. acanthocephalicus, P. heteropterum, Megalacanthus sp., and Echinostomatidae gen. sp. and Megalacanthus sp. had the highest MII and MA. There was a significant difference in the prevalence of $H$. acantocephalicus between female and male bird hosts. We report Echinostomatidae gen. sp., T. valida, Athesmia sp., Cyathostoma sp., A. carinii, P. minor, D. renale (larva), Baruscapillaria sp., and Megalacanthus sp. for the first time in P. infuscatus in Brazil.
\end{abstract}

Keywords: Nematoda, Trematoda, Digenea, Cestoda, parasitological index.

\section{Resumo}

As aves atuam como hospedeiros para uma ampla variedade de parasitos, muitos destes ainda desconhecidos. Foram examinadas 28 aves, provenientes dos municípios de Pelotas, Capão do Leão e Rio Grande. A coleta, preparação e identificação dos helmintos seguiu bibliografia específica. A assembleia de helmintos foi analisada através dos índices de prevalência (P\%), intensidade média de infecção (IMI) e abundância (AM). A assembleia de helmintos de P. infuscatus estava composta por Nematoda: Hystrichis acanthocephalicus, Dioctophyme renale (larva), Porrocaecum heteropterum, Baruscapillaria sp., Aproctella carinii, Paradeletrocephalus minor, Cyathostoma sp.; Digenea: Echinostomatidae gen. sp., Tanaisia valida, Athesmia sp. e Megalacanthus sp. (Cestoda). As espécies mais prevalentes foram: H. acanthocephalicus, P. heteropterum, Megalacanthus sp. e Echinostomatidae gen. sp. A maior IMI e AM foi de Megalacanthus sp., onde observouse diferença significativa na prevalência de $H$. acantocephalicus em hospedeiros fêmeas. Os helmintos Echinostomatidae gen. sp., T. valida, Athesmia sp., Cyathostoma sp., A. carinii, P. minor, D. renale (larva), Baruscapillaria sp., e Megalacanthus sp. são registrados pela primeira vez em $P$. infuscatus no Brasil.

Palavras-chave: Nematoda, Trematoda, Digenea, Cestoda, índices parasitológicos.

\section{Introduction}

Wildlife birds act as hosts for a wide variety of parasites. To date, many of which are unreported birds, especially the aquatic ones, constitute one of the fundamental groups for ecosystems,

Corresponding author: Simone Scheer. Laboratório de Parasitologia de Animais Silvestres - LAPASIL, Departamento de Microbiologia e Parasitologia, Instituto de Biologia, Universidade Federal de Pelotas - UFPel, Campus Universitário Capão do Leão, CP 354, CEP 96010-900, Pelotas, RS, Brasil. e-mail: sissi_sls@hotmail.com and act as excellent environmental sentinel species. They provide nourishment for other species, and help in the control of invasive plants, seed dispersal, and contribute to pollination (SICK, 2001). Moreover, aquatic birds can also disseminate pathogens including viruses, bacteria, and parasites. It is estimated that birds are the ones with the highest parasite diversity among all vertebrates (DOBSON et al., 2008), often these organisms are not seen as 
important components in terms of biodiversity (AMATO \& AMATO, 2010).

The bare-faced ibis Phimosus infuscatus (Lichtenstein, 1823) (Pelecaniformes: Threskiornithidae) is widely distributed in South America including Guyana, Venezuela, Bolivia, Paraguay, Argentina, Uruguay, and Brazil (SICK, 2001). It inhabits shallow water areas such as flooded fields, wetlands, lakes, rice paddies, and urban environments (BELTON, 2003).

There are reports of helminths parasitizing birds from the Threskiornithidae in different parts of the world. However, the helminth fauna of Phimosus infuscatus is little known (Table 1).

The objective of this study was to investigate the prevalence, mean abundance and mean intensity of infection of helminth parasites in $P$. infuscatus, and compare infections between male and female hosts.

\section{Materials and Methods}

Twenty-eight birds (15 males and 13 females) were examined postmortem, of which 21 were captured between December 2015 and February 2016 in the municipality of Rio Grande, State of Rio Grande do Sul, southern Brazil (31 $51^{\prime} 12.1^{\prime}$ S, 52¹8'48.0”W). The other birds $(\mathrm{n}=7)$ were donated by the Núcleo de Reabilitação da Fauna Silvestre and Centro de Triagem de Animais Silvestres da Universidade Federal de Pelotas (NURFS-CETAS/UFPel), where they were they had died. These birds were originated from

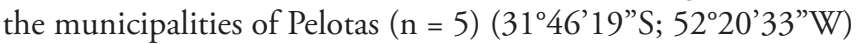
and Capão do Leão $(\mathrm{n}=2)$ ( $31^{\circ} 46^{\prime \prime} 3^{\prime \prime S}$; 52²6'55"W).

Euthanasia and sampling of these birds were authorized by the Instituto Chico Mendes de Conservação da Biodiversidade - (ICMBIO $\left.n^{\circ} 507541\right)$. The research proposal was approved by the Comissão de Ética em Experimentação Animal (CEEA/UFPel no 8876).

At necropsy, the oral cavity, nostrils, trachea, lungs, esophagus, gizzard, proventriculus, small intestine, cecum, large intestine, cloaca, pancreas, spleen, heart, kidneys, air sacs, and reproductive system were examined and helminths were collected. For parasite sampling, organs and their contents were washed using sieves with $150 \mu \mathrm{m}$ mesh pores.

Helminths were fixed in AFA (ethyl alcohol, formaldehyde, and acetic acid), and preserved in ethanol $70^{\circ} \mathrm{GL}$. Nematodes were clarified with Amann's lactophenol. Trematodes and cestodes were stained with Delafield hematoxylin or with Langeron's carmine (AMATO \& AMATO, 2010).
Nematodes were identified according to the taxonomic keys published by Lengy (1969), Hendricks et al. (1969), Measures \& Anderson (1985), Vicente et al. (1995), Hartwich (2009), Anderson et al. (2009), and Gibbons (2010). Morphological identification of digenetic trematodes was based on the taxonomic keys provided by Kanev et al. (2002), Kostadinova (2005), Pojmanska (2008), and Lunaschi et al. (2015). The identification of cestode was according to Bona (1994). The estimated parasitological indices were: Prevalence (P\%), Mean Intensity of infection (MII), Mean Abundance (MA) and Range (R) (BUSH et al., 1997).

$\mathrm{P} \%$ and MII were compared between males $(\mathrm{n}=15)$ and females ( $\mathrm{n}=13)$. P\% was compared using the Chi-square test $\left(\mathrm{X}^{2}\right)$ whereas MII was compared using the Bootstrap interval $(\mathrm{BC} \alpha, \mathrm{p}<0.05)$ in the software "Quantitative Parasitology - QP 3.0" (RÓZSA et al., 2000).

Voucher specimens were deposited in "Laboratório de Parasitologia de Animais Silvestres da Universidade Federal de Pelotas" (LAPASIL/UFPel), Pelotas, RS, Brazil, under accession numbers 636-706 and 712.

\section{Results}

All birds were parasitized by at least one species of helminth. Nematodes, cestodes, and digenetic trematodes had prevalences of $92.86 \%, 82.14 \%$ and $75 \%$, respectively. Helminths assemblage of $P$. infuscatus in southern Brazil included the following: Nematoda: Hystrichis acanthocephalicus (Molin, 1861), Dioctophyme renale (Goeze, 1782) (larva), (Enoplida: Dioctophymatidae), Baruscapillaria sp. (Enoplida: Trichuridae), Cyathostoma sp. (Strongylida: Syngamidae), Paradeletrocephalus minor (Molin, 1861) (Strongylida: Deletrocephalidae), Porrocaecum heteropterum (Diesing, 1851) (Ascaridida: Ascarididae), Aproctella carinii (Pereira \& Vaz, 1933) (Spirurida: Onchocercidae); Trematoda, Digenea: Echinostomatidae gen. sp., Tanaisia valida (Freitas, 1951) (Eucotylidae), Athesmia sp. (Dicrocoeliidae); and Cestoda: Megalacanthus sp. (Cyclophyllidea: Dilepididae).

The helminths $H$. acanthocephalicus, Megalacanthus sp., Echinostomatidae gen. sp., and $P$. heteropterum were the most prevalent, and occurred in $89.28 \%, 89.28 \%, 82.14 \%$ and $50 \%$ of birds necropsied, respectively (Table 2 ).

Although $H$. acanthocephalicus occurred in $89.28 \%$ of the birds, it had low levels of MII (3.87) and MA (3.17). In contrast, Megalacanthus sp. presented the highest parasitological indexes of

Table 1. Helminth fauna of the bare-faced ibis Phimosus infuscatus in South America.

\begin{tabular}{|c|c|c|c|}
\hline & Helminth & Location & Reference \\
\hline \multirow[t]{5}{*}{ Nematoda } & Hystrichis acantocephalicus Molin, 1861 & Brazil & Vicente et al. (1995); Scheer et al. (2017) \\
\hline & Eustrongylides ignotus Jagerskiold, 1909 & Brazil & \\
\hline & Tetrameres sp. & Brazil & Spalding and Forrester, (1993) \\
\hline & Porrocaecum sp. & Brazil & Vicente et al. (1995) \\
\hline & Porrocaecum heteropterum Diesing, 1851 & Brazil & Vicente et al. (1995) \\
\hline Trematoda & Stomylotrema sp. & Brazil & Travassos and Freitas (1942) \\
\hline Cestoda & Chimaerula bonai Georgiev e Vaucher, 2000 & Paraguay & Georgiev and Vaucher, $(2000)$ \\
\hline
\end{tabular}


Table 2. Helminths of Phimosus infuscatus $(\mathrm{n}=28)$ in southern Brazil and their respective infection sites and parasitological indexes.

\begin{tabular}{|c|c|c|c|c|c|}
\hline Helminths & Site of Infection & $\mathbf{P}(\%)$ & MII (SD)* & MA (SD)* & $\mathbf{R}$ \\
\hline \multicolumn{6}{|l|}{ Nematoda } \\
\hline Hystrichis acanthocephalicus & Proventricle & 89.28 & $3.87( \pm 5.26)$ & $3.17( \pm 5.0)$ & $1-18$ \\
\hline Dioctophyme renale (larva) & Esophagus & 3.57 & 1 & 0.03 & 1 \\
\hline Porrocaecum heteropterum & Small intestine, gizzard & 50 & $29.5( \pm 74.65)$ & $12.64( \pm 50.0)$ & $2-265$ \\
\hline Baruscapillaria sp. & Small intestine & 1.71 & $13( \pm 11.53)$ & $1.39( \pm 5.16)$ & $4-26$ \\
\hline Aproctella carinii & Small intestine & 7.14 & $1.5( \pm 0.71)$ & $0.11( \pm 0.42)$ & $1-2$ \\
\hline Paradeletrocephalus minor & Abdominal cavity & 3.57 & 1 & 0.03 & 1 \\
\hline Cyathostoma sp. & Trachea & 3.57 & 10 & 0.35 & 10 \\
\hline \multicolumn{6}{|l|}{ Digenea } \\
\hline Echinostamatidae gen. sp. & Small intestine & 82.14 & $24.23( \pm 28.27)$ & $18.17( \pm 26.58)$ & $2-135$ \\
\hline Tanaisia valida & Renal ducts & 3.57 & 5 & 0.17 & 5 \\
\hline Athesmia sp. & Renal ducts & 3.57 & 11 & 0.39 & 11 \\
\hline \multicolumn{6}{|l|}{ Cestoda } \\
\hline Megalacanthus sp. & Small intestine & 89.28 & $48.26( \pm 64.28)$ & $39.64( \pm 61.0)$ & $1-278$ \\
\hline
\end{tabular}

P\% (Prevalence), MII (Mean intensity of infection), MA (Mean abundance), R (Range); ${ }^{*} \mathrm{SD}=$ Standard Deviation.

the assemblage: $\mathrm{MII}=48.26$ helminths/host (1-278), $\mathrm{MA}=39.64$ and Echinostomatidae gen. sp. and $P$. hetoropterum had similar MII and MA (Table 2).

With regard to the prevalence of helminth infections in male birds and female birds, it was observed that $H$. acanthocephalicus, P. heteropterum, Baruscapillaria sp., Echinostomatidae gen. sp., and Megalacanthus sp. were common in both males and females. There were no significant difference in the P\% and MII of these helminths according to the host's genders, except for $H$. acanthocephalicus, which was significantly more prevalent in females $(\mathrm{P}=100 \%)$ than in males ( $\mathrm{P}=66.7 \%)$ (Table 3). The helminths Cyathostoma sp., T. valida, and Athesmia sp. were found only in females, whereas $D$. renale (larva), $P$. minor, and $A$. carinii were found only in males with low infection rates (Table 3 ).

\section{Discussion}

The P\%, MII, and MA indexes of $H$. acanthocephalicus, P. heteropterum, Echimostomatidae gen. sp., and Megalacanthus sp. suggest that these helminths are common in P. infuscatus.

These indexes may reflect prey-predator interactions as these helminths have an indirect life cycle in which intermediate hosts and/or paratenic hosts are involved and may be part of the bird's diet.

Hystrichis spp. have been reported in many avian hosts and in several countries in lower prevalences (KINSELLA et al., 1973; CANARIS et al., 2010). In Brazil, $H$. acanthocephalicus only was reported in the proventricular glands of $P$. infuscatus, $\mathrm{P}=89.28 \%$ (SCHEER et al., 2017).

Porrocaecum spp. are ascarids that occur in the digestive tract of birds, reptiles, fish, and mammals (HARTWICH, 2009). According to Digiani \& Sutton (2001), there are approximately 40 species of Porrocaecum reported to date, with the highest prevalence in wading birds from the Threskiornithidae that inhabit the Neotropical region.

In Guaminí and Rahue, Argentina, Digiani \& Sutton (2001) reported $P$. heteropterum in the Plegadis chihi (Vieillot, 1817) (Pelecaniformes: Threskiornithidae) and Theristicus melanopis melanopis (Gmelin, 1789) in the small intestine of birds. In P. chibi, one of the seven birds was parasitized, in which 11 helminths were found. In T. melanopis ( $\mathrm{n}=5), 2$ birds were parasitized with P. heteropterum. Digiani \& Sutton (2001) also examined 56 P. chihi from Punta Blanca, Argentina, and this helminth was not found in any of the birds necropsied. However, in the present survey, significant numbers of $P$. heteropterum were found in $P$. infuscatus (Table 2). In Brazil, Vicente et al. (1995) reported P. heteropterum in the small intestine of P. infuscatus and T. caudatus (Boddaert, 1783) (Pelecaniformes: Threskiornithidae). However, information on parasitological indexes is not available.

In Brazil, cestodes belonging to the Dilepididae have been documented in several birds of the Threskiornithidae. Parasitological indexes have not been reported though (BONA, 1975). Bona (1994) cited, for Brazil, Megalacanthus macracantha Furhrmann, 1908, in Belonopterus chilensis cayennensis (Molina, 1982) (Charadriiformes: Charadriidae) and Megalacanthus rostellata Furhmann, 1908 without identifying their host. In Paraguay, the cestode Chimaerula bonai was recorded in P. infuscatus with a prevalence of $100 \%(n=4)$ (GEORGIEV \& VAUCHER, 2000). In P. infuscatus, Megalacanthus sp. was present in all indexes analyzed, which suggests that this avian host plays an important role in the life cycle of the helminth in this geographic region (Table 2).

Echinostomatidae Looss, 1899, consists of intestinal digeneans that occur in birds, mammals, and humans, and has a broad geographic distribution. It comprises 355 species and 50 genera. Due to its diversity, many authors report difficulties in the taxonomic identification of members of this family (KOSTADINOVA, 2005). All specimens found parasitizing $P$. infuscatus belong to the same species, however it was not possible their identification into genus level with the references available. In Argentina, Digiani (2000) reported Dietziella egregia (Dietz, 1909) in P. chihi $(\mathrm{n}=62)$ with prevalence of $46.7 \%$, and MII = 82.35. Dronen \& Blend (2008) described Patagifer lamothei in Eudocimus albus Linnaeus, 1758 (Pelecaniformes: Threskiornithidae) $(n=8)$ in the State of Texas, USA with $\mathrm{P}=25 \%$ and $\mathrm{MII}=6$. Both birds have very similar habits to those of the avian host studied in our survey. 
The other helminths found in P. infuscatus had low parasitological indexes. Cyathostoma sp., P. minor, D. renale (larva), T. valida, and Athesmia sp. were found infecting one host. This finding suggests that infections may have been accidental through ingestion of intermediate or paratenic hosts. The diet of $P$. infuscatus is composed of annelids, molluscs, and insects (BELTON, 2003), and these invertebrates may participate in the life cycle of these helminths (Table 4).

Nematodes Syngamidae Leiper, 1912, may be present in the respiratory and digestive tracts and body cavities of mammals, rodents, and birds. They are known to live in copula, except for Cyathostoma (BORGSTEEDE \& OKULEWICZ, 2001). According

Table 3. Parasitological indexes in male and female Phimosus infuscatus in southern Brazil.

\begin{tabular}{|c|c|c|c|}
\hline \multirow{2}{*}{ Helminths } & \multirow{2}{*}{ Parasitological Indexes } & \multicolumn{2}{|c|}{ Hosts' Sex } \\
\hline & & Male $(n=15)$ & Female $(n=13)$ \\
\hline \multirow[t]{4}{*}{ Hystrichis acanthocephalicus } & $\mathrm{P} \%$ & 66.7 & $100^{*}$ \\
\hline & MII (SD) & $3.4( \pm 2.5)$ & $4.23( \pm 6.76)$ \\
\hline & MA (SD) & $2.26( \pm 2.60)$ & $4.23( \pm 6.76)$ \\
\hline & $\mathrm{R}$ & $1-10$ & $1-26$ \\
\hline \multirow[t]{4}{*}{ Dioctophyme renale (larva) } & $\mathrm{P} \%$ & 6.66 & 0 \\
\hline & MII (SD) & 1 & 0 \\
\hline & MA (SD) & $0.06( \pm 0.26)$ & 0 \\
\hline & $\mathrm{R}$ & 1 & 0 \\
\hline \multirow[t]{4}{*}{ Porrocaecum heteropterum } & $\mathrm{P} \%$ & 53.3 & 30,8 \\
\hline & MII (SD) & $9.88( \pm 9.95)$ & $68.75( \pm 130.84)$ \\
\hline & MA (SD) & $5.26( \pm 8.69)$ & $21.15( \pm 73.28)$ \\
\hline & $\mathrm{R}$ & $3-34$ & $2-265$ \\
\hline \multirow[t]{4}{*}{ Baruscapillaria sp. } & $\mathrm{P} \%$ & 6.7 & 15.4 \\
\hline & MII (SD) & 9 & $15( \pm 15.56)$ \\
\hline & $\mathrm{MA}(\mathrm{SD})$ & $0.6( \pm 2.32)$ & $2.39( \pm 7.20)$ \\
\hline & $\mathrm{R}$ & 9 & $4-26$ \\
\hline \multirow[t]{4}{*}{ Aproctella carinii } & $\mathrm{P} \%$ & 13.33 & 0 \\
\hline & MII (SD) & $1.5( \pm 0.71)$ & 0 \\
\hline & $\mathrm{MA}(\mathrm{SD})$ & $0.2( \pm 0.56)$ & 0 \\
\hline & $\mathrm{R}$ & $1-2$ & 0 \\
\hline \multirow[t]{4}{*}{ Paradeletrocephalus minor } & $\mathrm{P} \%$ & 6.66 & 0 \\
\hline & MII (SD) & 1 & 0 \\
\hline & MA (SD) & $0.06( \pm 0.26)$ & 0 \\
\hline & $\mathrm{R}$ & 1 & 0 \\
\hline \multirow[t]{4}{*}{ Cyathostoma sp. } & $\mathrm{P} \%$ & 0 & $7.7 \%$ \\
\hline & MII (SD) & 0 & 10 \\
\hline & MA (SD) & 0 & 0.76 \\
\hline & $\mathrm{R}$ & 0 & 10 \\
\hline \multirow[t]{4}{*}{ Echinostomatidae gen. sp. } & $\mathrm{P} \%$ & 75 & 76.9 \\
\hline & MII (SD) & $21.90( \pm 25.68)$ & $26,8( \pm 32,09)$ \\
\hline & MA (SD) & $18.13( \pm 23.91)$ & $31( \pm 30.17)$ \\
\hline & $\mathrm{R}$ & $3-92$ & $5-135$ \\
\hline \multirow[t]{4}{*}{ Tanaisia valida } & $\mathrm{P} \%$ & 0 & 6.66 \\
\hline & MII (SD) & 0 & 5 \\
\hline & MA (SD) & 0 & $0.33( \pm 1.39)$ \\
\hline & $\mathrm{R}$ & 0 & 5 \\
\hline \multirow[t]{4}{*}{ Athesmia sp. } & $\mathrm{P} \%$ & 0 & 6.66 \\
\hline & MII (SD) & 0 & 11 \\
\hline & MA (SD) & 0 & $0.73( \pm 3.05)$ \\
\hline & $\mathrm{R}$ & 0 & 11 \\
\hline \multirow[t]{4}{*}{ Megalacanthus sp. } & $\mathrm{P} \%$ & 73.3 & 92.3 \\
\hline & MII (SD) & $24.09( \pm 40.07)$ & $70.42( \pm 75.39)$ \\
\hline & $\mathrm{MA}(\mathrm{SD})$ & $18.86( \pm 35.61)$ & $65.15( \pm 74.76)$ \\
\hline & $\mathrm{R}$ & $1-137$ & $2-278$ \\
\hline
\end{tabular}


Table 4. Helminth parasites of Phimosus infuscatus in southern Brazil and their respective intermediate and paratenic hosts, considering the information available for life cycles of congeners species or species of the same family.

\begin{tabular}{|c|c|c|c|}
\hline Taxon & Intermediate host & Paratenic host & References \\
\hline \multicolumn{4}{|l|}{ Nematoda } \\
\hline Hystrichis acanthocephalicus & Aquatic oligochaetes & anurans & Anderson (2000) \\
\hline Porrocaecum heteropterum & Aquatic oligochaetes & & Anderson (2000) \\
\hline Dioctophyme renale (larva) & Aquatic oligochaetes & & Anderson (2000) \\
\hline Aproctela carinii & Mosquitoes (Culicidae) & & Anderson (2000) \\
\hline Baruscapillaria sp. & Monoxene & & Anderson (2000) \\
\hline Paradeletrocephalus minor & Monoxene & & Anderson (2000) \\
\hline Cyathostoma sp. & Monoxene & $\begin{array}{l}\text { earthworms, mollusks, } \\
\text { ants and beetles }\end{array}$ & Atkinson et al. (2009) \\
\hline \multicolumn{4}{|l|}{ Digenea } \\
\hline Echinostomatidae gen. sp. & $\begin{array}{l}\text { Sweet and sweet gastropod } \\
\text { molluscs larvae of anurans }\end{array}$ & & Esteban and Muńoz-Antoli (2009) \\
\hline Athesmia sp. (Dicrocoeliidae) & Mollusks and arthropods & amphibians and reptiles & Pojmanska (2008) \\
\hline Tanaisia valida (Tanaisiinae) & Mollusks & & Lunaschi et al. (2015) \\
\hline \multicolumn{4}{|l|}{ Cestoda } \\
\hline Megalacanthus sp. (Dilepididae) & Annelids, mollusks and arthropods & & Olsen (1974) \\
\hline
\end{tabular}

to Kanarek (2009), there are six species of Cyathostoma that occur in birds of different orders such as Anseriformes, Charadriiformes, Casuariiformes, Ciconiiformes, Columbiformes, Coraciiformes, Galliformes, Gaviiformes, Gruiformes, Falconiformes, Passeriformes, Pelecaniformes, Psittaciformes, Strigiformes, Struthioniformes, and Sphenisciformes. Cyathostoma phenisci (Baudet, 1937) was reported in Pelecanus erythrorhynchus Gmelin, 1789 (Pelecanidae), in North America (OVERSTREET \& CURRAN, 2005). Nevertheless, these studies did not report infection rates. In the State of Florida, USA, Courtney \& Forrester (1974) reported the occurrence of $C$. phenisci in Pelecanus occidentalis Linnaeus, 1766 (Pelecanidae) ( $\mathrm{n}=$ 57 ), with an intensity of one to four nematodes which were present in the trachea, lungs, and air sacs. The results of the present study are similar to those reported by Courtney \& Forrester (1974) since the prevalence of the infection by this nematode was considered low. The life cycle of Cyathostoma include paratenic hosts that can be ingested by $P$. infuscatus (Table 4).

Deletrocephalidae Chitwood, 1969, comprises Deletrocephalus Diesing, 1851, and Paradeletrocephalus Freitas \& Lent, 1947, which include species commonly found in the large intestine of ratites. They have been often reported in the greater rhea Rhea americana (Linnaeus, 1758) (Rheiformes: Rheidae) in Brazil, Argentina, and Europe (GORDO et al., 2002; ACOMOLLI et al., 2006; HOFFMANN et al., 2009). The association between $P$. minor and $P$. infuscatus may be related to the bird's feeding habits and habitat. The low parasitological indexes in $P$. infuscatus and the biology of members of Deletrocephalidae (Table 4) suggest that infections may have been accidental.

Likewise, infection by a larva of Dioctophyme renale (Goeze, 1782) in an avian host may be considered accidental. This nematode is a parasite of wild and domestic mammals and has aquatic oligochaetes, anurans, and fish as intermediate and paratenic hosts, respectively (Table 4) (ANDERSON, 2000).

In aquatic birds in the same region, southern Brazil, Bernardon et al. (2017) documented Baruscapillaria sp. in Ardeidae, Egretta thula (Molina, 1782) $(\mathrm{n}=6)$ and Ardea cocoi
Linnaeus, 1766 ( $\mathrm{n}=5$ ) (Pelecaniformes) with $\mathrm{P}=66.6 \%, 40 \%$, $\mathrm{MA}=2.3$ and 1.2 and $\mathrm{MII}=3.5$ e 3.0 , respectively, differing in our research (Table 2). The life cycle of Baruscapillaria obsignata (Madsen, 1945) is well-known (ANDERSON, 2000) (Table 4). Aproctella carinii and T. valida were reported in Passeriformes from same region with indexes of infection differing in our research (MASCARENHAS et al., 2009; BERNARDON et al., 2016)

In Argentina, in hosts Threskiornithidae, $A$. heterolechithodes was reported in $T$. caudatus ( $\mathrm{n}=1$ ) with $\mathrm{MII}=15$ (LUNASCHI et al., 2015), and in $P$. chihi $(\mathrm{n}=60)$ with $\mathrm{P}=8.8 \%$ and MII=8.2 (DIGIANI, 2000). In our research the indexes were similar (Table 2).

The diet of $P$. infuscatus is composed of annelids, molluscs, and insects (BELTON, 2003) which are the intermediate or paratenic hosts (or both) (Table 4) of many of the helminths reported in this survey.

The presence of helminth infections in males and females of endothermic hosts may indicate that the highest prevalence is due to morphological, physiological, and behavioral aspects such as territorialism and social interaction which may vary throughout the life of the host (POULIN, 1996).

The low prevalence of some helminth species may be related to low levels of natural infection and low availability of intermediate hosts in the environment (ROBINSON et al., 2008).

In the State of Rio Grande do Sul, studies carried out in Turdus rufiventris Vieillot, 1818, (Passeriformes: Turdidae) $(\mathrm{n}=151)$ (CALEGARO-MARQUES \& AMATO, 2010) and in Phalacrocorax brasilianus (Gmelin, 1789) (Suliformes: Phalacrocoracidae) ( $\mathrm{n}=47)$ (MONTEIRO et al., 2011) assessed the correlation between the gender of hosts and the occurrence of helminth infections. There were no differences between males and females in terms of the composition and parasitological indexes of helminths. These results are similar to those found in P. infuscatus and is attributed to the similar diet and the habitat shared by males and females. 


\section{Conclusions}

The infection rates allow us to conclude that helminths Hystrichis acanthocephalicus, Porrocaecum heteropterum, Echinostomatidae gen. sp., and Megalacanthus sp. are common in the assembly of $P$. infuscatus from southern Brazil.

The nematodes Cyathostoma sp., Aproctella carinii, Paradeletrocephalus minor, Dioctophyme renale (larva), and Baruscapillaria sp., the digenetic trematodes Echinostomatidae gen. sp., Tanaisia valida, and Athesmia sp., and the cestode Megalacanthus sp. are reported for the first time in P. infuscatus in Brazil.

With regard to male and female avian hosts, both have a similar helminth fauna, except for $H$. acanthocephalicus, which was more prevalent in females.

\section{Acknowledgements}

We thank the Núcleo de Reabilitaçáo da Fauna Silvestre/ Universidade Federal de Pelotas (UFPel) for the donation of birds, and the Instituto Chico Mendes de Conservação da Biodiversidade for the authorization to capture the birds for this research.

\section{References}

Acomolli J, Ocayo D, Cruz ACS, Milano F, Roux JP. Aspectos morfológicos de Paradeletrocephalus minor (Molin, 1861) Freitas \& Lent, 1947, en ñandu (Rhea americana), por medio de miscroscopio de luz y microscopio electrónico de barrido. Parasitol Latinoam 2006; 61(3-4): 183-187. http:// dx.doi.org/10.4067/S0717-77122006000200016.

Amato JFR, Amato SB. Técnicas gerais para coleta e preparaçáo de helmintos endoparasitos de aves. In: Von Matter S, Straube FC, Piacentini VQ, Accordi IA, Cândido JF Jr. Ornitologia e conservaçâo: ciência aplicada, técnicas de pesquisa e levantamento. Rio de Janeiro: Technical Books; 2010. p. 367-394.

Anderson RC, Chabaud AG, Willmott S. Keys to the nematode parasites of vertebrates: arquival volume. London: CABI International; 2009.

Anderson RC. Nematode parasites of vertebrates: their development and transmission. London: CABI International; 2000. http://dx.doi.org/10. 1079/9780851994215.0000.

Atkinson CT, Thomas NJ, Hunter DB. Parasitic diseases of wild birds. John Wiley \& Sons, 2009.

Belton W. Aves do Rio Grande do Sul: distribuiçâo e biologia. São Leopoldo: Editora UNISINOS; 2003.

Bernardon FF, Soares TL, Vieira TD, Müller G. Helminths of Molothrus bonariensis (Gmelin, 1789) (Passeriformes: Icteridae) from southernmost Brazil. Rev Bras Parasitol Vet 2016; 25(3): 279-285. http://dx.doi. org/10.1590/S1984-29612016042. PMid:27580390.

Bernardon FF, Valente ALS, Muller G. Helminth assemblage of aquatic birds (Pelecaniformes: Ardeidae) of southern Rio Grande and a checklist of helminths of herons of Brazil. Neotrop Helminthol 2017; 11(2): 357-375.

Bona FV. Étude critique et taxonomique des Dilepididae Fubrm., 1907 (Cestoda) parasites des Ciconiiformes. Considérations sur la spécificité et la speciation [Monografia]. Roma: Consiglio Nazionale delle Ricerche; 1975.
Bona FV. Family Dilepididae Railliet \& Henry, 1909. In: Khalil LF, Jones A, Bray RA. Keys to the cestode parasites of vertebrates. CAB International; 1994.

Borgsteede FHM, Okulewicz A. Justification of the species Cyathostoma (Hovorkonema) americana (Chapin, 1925) (Syngamidae - Nematoda). Helminthologia 2001; 38: 151-154.

Bush AO, Lafferty KD, Lotz JM, Shostak AW. Parasitology meets ecology on its own terms: Margolis et al. revisited. J Parasitol 1997; 83(4): 575583. http://dx.doi.org/10.2307/3284227. PMid:9267395.

Calegaro-Marques C, Amato SB. Parasites as secret files of the trophic interactions of hosts: the case of the rufous-bellied thrush. Rev Mex Biodivers 2010; 81(3): 801-811.

Canaris AG, Ortiz R, Canaris GJ. A predictable suite of helminth parasites in the long-billed dowitcher, Limnodromus scolopaceus, from the Chihuahua Desert in Texas and Mexico. J Parasitol 2010; 96(6): 1060-1065. http:// dx.doi.org/10.1645/GE-2503.1. PMid:21158610.

Courtney CH, Forrester DJ. Helminth parasites of brown pelican in Florida and louisiana. Proc Helminthol Soc Wash 1974; 41(1): 89-93.

Digiani MC, Sutton CA. New reports and a redescription of Porrocaecum heteropterum (Diesing, 1851) (Ascarididae), a rare nematode parasitic in South American threskiornithid birds. Syst Parasitol 2001; 49(1): 1-6. http://dx.doi.org/10.1023/A:1010730611828. PMid:11389327.

Digiani MC. Digeneans and cestodes parasitic in the white-faced ibis Plegadis chihi (Aves: Threskiornithidae) from Argentina. Folia Parasitol (Praha) 2000; 47(3): 195-204. http://dx.doi.org/10.14411/fp.2000.037. PMid:11104147.

Dobson A, Lafferty KD, Kuris AM, Hechinger RF, Jetz W. Homage to Linnaeus: How many parasites? How many hosts? Proc Natl Acad Sci USA 2008; 105(Suppl 1): 11482-11489. http://dx.doi.org/10.1073/ pnas.0803232105. PMid:18695218.

Dronen NO, Blend CK. Patagifer lamothei n. sp. (Digenea: Echinostomatidae: Nephrostominae) from the white ibis Eudocimus albus (Threskiornithidae) from Texas, USA. Rev Mex Biodivers 2008; 79: 23-32.

Esteban JG, Muñoz-Antoli C. Echinostomes: systematics and life cycles. In: Toledo R, Fried B (eds). The biology of echinostomes. New York: Springer; 2009. p.1-34. http://dx.doi.org/10.1007/978-0-387-09577-6_1.

Georgiev BB, Vaucher C. Chimaerula bonai sp. n. (Cestoda: Dilepididae) from the bare-faced ibis, Phimosus infuscatus (Lichtenstein) (Aves: Threskiornithidae) in Paraguay. Folia Parasitol (Praha) 2000; 47(4): 303-308. http://dx.doi.org/10.14411/fp.2000.052. PMid:11151955.

Gibbons LM. Keys to the nematoda parasites of vertebrates: supplementary volume. London: CABI; 2010.

Gordo FP, Herrera S, Castro AT, Durán BG, Díaz RM. Parasites from farmed ostriches (Struthio camelus) and rheas (Rhea americana) in Europe. Vet Parasitol 2002; 107(1-2): 137-160. http://dx.doi.org/10.1016/S03044017(02)00104-8. PMid:12072221.

Hartwich G. Superfamília Ascaridoidea. In: Anderson RC, Chabaud AG, Willmott S. Keys to the Nematode Parasites of Vertebrates: archival volume. London: CABI; 2009. p. 309-323.

Hendricks LD, Harkema R, Miller GC. Hystrichis corvi sp. n. (Nematoda: Dioctophymatidae) from the Crow, and a Revised Key to the Species of Hystrichis. J Parasitol 1969; 55(6): 1201-1204. http://dx.doi. org/10.2307/3277258. 
Hoffmann RP, Mattos MT, Marques SMT, Bastos JH, Albuquerque C, Diaz J. Paradeletrocephalus minor (Molin, 1861) Freitas \& Lent, 1947, em ema (Rhea americana) no Rio Grande do Sul, Brasil. Rev Ibero-Lat Parasitol 2009; 68(2): 196-198.

Kanarek G. The occurrence of Cyathostoma (Cyathostoma) microspiculum (Skrjabin, 1915) (Nematoda: Syngamidae) in the great cormorant Phalacrocorax carbo (L., 1758) in north-eastern Poland. J Helminthol 2009; 83(4): 391-398. http://dx.doi.org/10.1017/S0022149X09990307. PMid:19531273.

Kanev I, Radev V, Fried B. Family Eucotylidae Cohn, 1904. In: Gibbon DI, Jones A, Bray RA. Keys to the Trematoda. London: CABI; 2002. p. 147-152. (vol. 1).

Kinsella JM, Hon L, Reed PB Jr. A comparison of the helminth parasites of the common gallinule (Gallinula chloropus cachinnans) and the purple gallinule (Porphyrula martinica) in Florida. Am Midl Nat 1973; 89(2): 467-473. http://dx.doi.org/10.2307/2424053.

Kostadinova A. Family Echinostomatidae Looss, 1899. In: Gibbon ID, Jones A, Bray RA. Keys to the trematoda. Volume 2. London: CABI Publishing and The Natural History; 2005. p. 5-8.

Lengy J. Notes on the classification of Syngamidae (Nematoda) with new data on some of the species. Isr J Zool 1969; 18(1): 9-23. PMid:5364988.

Lunaschi LI, Drago FB, Draghi R. Redescription of Tanaisia dubia (Digenea) from the northeast region of Argentina, with a key to Neotropical species of the genus, and a key to genera of Tanaisiinae. Rev Mex Biodivers 2015; 86(4): 888-895. http://dx.doi.org/10.1016/j.rmb.2015.06.012.

Mascarenhas CS, Krüger C, Müller G. The helminth fauna of the redcrested cardinal (Paroaria coronata) Passeriformes: Emberizidae in Brazil. Parasitol Res 2009; 105(5): 1359-1363. http://dx.doi.org/10.1007/ s00436-009-1569-8. PMid:19636590.

Measures LN, Anderson RC. Centrarchid fish as paratenic hosts of the giant kidney worm, Dioctophyma renale (Goeze, 1782), in Ontario, Canada. JWildl Dis 1985; 21(1): 11-19. http://dx.doi.org/10.7589/00903558-21.1.11. PMid:3157009.

Monteiro CM, Amato JF, Amato SB. Helminth parasitism in the Neotropical cormorant, Phalacrocorax brasilianus, in Southern Brazil: effect of host size, weight, sex, and maturity state. Parasitol Res 2011; 109(3): 849855. http://dx.doi.org/10.1007/s00436-011-2311-x. PMid:21431903.

Olsen OW. Animal parasites: their biology and life cycles. Baltimore: University Park Press; 1974.

Overstreet RM, Curran SS. Parasites of the American white pelican. Gulf Caribb Res 2005; 17: 31-48. http://dx.doi.org/10.18785/gcr.1701.04.

Pojmanska T. Family Dicrocoeliidae Looss, 1899. In: Gibbon DI, Jones A, Bray RA. Keys to the Trematoda. 3nd ed. London: CABI; 2008. p. 233-260.

Poulin R. Sexual inequalities in helminth infections: a cost of being a male? Am Nat 1996; 147(2): 287-295. http://dx.doi.org/10.1086/285851.

Robinson SA, Forbes MR, Hebert CE, McLaughlin DJ. Male-biased parasitism by common helminths is not explained by sex differences in body size or spleen mass of breeding cormorants Phalacrocorax auritus. J Avian Biol 2008; 39(3): 272-276. http://dx.doi.org/10.1111/j.09088857.2008.04340.x.

Rózsa L, Reiczigel J, Majoros G. Quantifying parasites in samples of hosts. J Parasitol 2000; 86(2): 228-232. http://dx.doi.org/10.1645/00223395(2000)086[0228:QPISOH]2.0.CO;2. PMid:10780537.

Scheer S, Macedo MRP, Soares MP, Schramm CC, Muller G. Pathology and morphometry of Hystrichis acanthocephalicus (Nematoda) from Phimosus infuscatus (Pelecaniformes) in southern Brazil. Rev Bras Parasitol Vet 2017; 26(1): 34-38. http://dx.doi.org/10.1590/s1984-29612016089. PMid:28146154.

Sick H. Ornitologia brasileira. Rio de Janeiro: Nova Fronteira; 2001.

Spalding MG, Forrester DJ. Pathogenesis of Eustrongylides ignotus (Nematoda: Dioctophymatoidea) in Ciconiiformes. J Wildl Dis 1993; 29(2): 250-260. http://dx.doi.org/10.7589/0090-3558-29.2.250. PMid:8487374

Travassos L, Freitas JFT. Relatório da sexta excursão do Instituto Oswaldo Cruz, realizada à zona da Estrada de Ferro Noroeste do Brasil, em novembro de 1941. Mem Inst Oswaldo Cruz 1942; 37(3): 259-286. http://dx.doi. org/10.1590/S0074-02761942000300004.

Vicente JJ, Rodrigues HO, Gomes DC, Pinto RM. Nematóides do Brasil. Parte IV: Nematóides de aves. Rev Bras Zool 1995; 12(Suppl 1): 1-273. http://dx.doi.org/10.1590/S0101-81751995000500001. 